\title{
Belgeo
}

Revue belge de géographie

$4 \mid 2013$

Miscellaneous

\section{Quality of life in Argentina: The environmental dimension at a departmental scale}

La qualité de vie en Argentine : dimension environnementale à l'échelle des départements

\section{Guillermo Ángel Velázquez et Juan Pablo Celemín}

\section{OpenEdition}

Journals

Édition électronique

URL : http://journals.openedition.org/belgeo/11794

DOI : 10.4000/belgeo. 11794

ISSN : 2294-9135

Éditeur :

National Committee of Geography of Belgium, Société Royale Belge de Géographie

Édition imprimée

Date de publication : 31 décembre 2013

ISSN : 1377-2368

\section{Référence électronique}

Guillermo Ángel Velázquez et Juan Pablo Celemín, « Quality of life in Argentina: The environmental dimension at a departmental scale », Belgeo [En ligne], 4 | 2013, mis en ligne le 30 juin 2014, consulté le 30 avril 2019. URL : http://journals.openedition.org/belgeo/11794; DOI : 10.4000/belgeo.11794

Ce document a été généré automatiquement le 30 avril 2019.

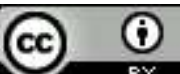

Belgeo est mis à disposition selon les termes de la licence Creative Commons Attribution 4.0 International. 


\title{
Quality of life in Argentina: The environmental dimension at a departmental scale
}

\author{
La qualité de vie en Argentine : dimension environnementale à l'échelle des \\ départements
}

Guillermo Ángel Velázquez et Juan Pablo Celemín

\section{Introduction}

1 The analysis of the Quality of Life from a geographic perspective relies mainly on the development of indices with the highest possible level of territorial disaggregation and reflecting the relative wellbeing of the population. Earlier indices developed for Argentina (Velázquez, 2008; 2010a) provided basically two dimensions: a) socio-economic and b) environmental. Socio-economic dimension embraces such indicators as education, health and housing, while environmental one considers three aspects: nature-based recreational resources, socially constructed recreational resources and environmental problems.

2 Given the fact that the environmental dimension is a key component of wellbeing, the purpose of this work is to develop and to analyse the spatial distribution of an Environmental Quality Index (EQI) applied to departments, third-order spatial units in Argentina. For each unit, we considered recreational resources, both naturally and socially constructed and environmental problems. The main purpose of this EQI is to measure the magnitude of the environmental aspects affecting population wellbeing.

3 To formulate a relevant EQI with respect to population wellbeing, it is necessary to provide a broad definition of the environment that includes the different relationships between society and the physical environment, whether built or artificial, which take place in bounded spaces. It involves considering, on a simultaneous basis, juxtaposed land uses, multiple processes and social actors (Herzer and Gurevich, 1996), producing an 
environment whose main feature is to be "socially constructed", and rendering it clearly different from the "natural" environment (Metzger, 2006).

Generally speaking, quality of life indices incorporate common environmental variables associated with pollution, water quality, and natural features, among others (Andrews, 2001; Rahman et al.). Others also encompass variables related to urban environmental quality, i.e., transport and security. However, they tend to overlook a central feature: nature-based recreational resources and socially constructed recreational resources. Even though some studies link tourism to the living conditions of the population, few stress the role that "cultural industries" play in the growth and development of a locality and in improving urban aesthetics. An exception to the above stated is a work by Nissan (1997) who developed an index for the arts (culture) and recreation based on 20 variables for the major metropolitan areas of Canada and the United States.

5 Environmental quality is a vague concept addressed by multiple disciplines. It is often related to other notions, also diffuse and complex, such as quality of life, sustainability, livability (Van Kamp et al., 2003), environmental inequity and environmental justice. In fact, in Fishbein's words (1969, p. 2130), the quality of the environment really means the quality of life, since it is a social phenomenon. It is social because man is the focus of concern. Given the versatility of the concept, Escobar (2006) indicates that environmental quality can be conceived as a component of sustainable urban development, even including economic and social conditions.

6 The spatial expression of the environmental quality is similar to the spatial performance of other social end economic indicators in Latin America. As a consequence, a new concept called environmental inequality emerges, according to which social sectors with fewer resources are often more exposed and affected by environmental problems (air pollution, poor quality housing, dirty streets, high traffic and few local amenities). This sector also has less access to environmental assets (sufficient energy, healthy food and clean water), a fact with long-lasting deleterious effects on health and welfare (CatalanVazquez and Jarillo-Soto, 2010). Therefore the notion of environmental inequity refers to a specific social group that is significantly affected by environmental risks, unlike environmental justice with which it is closely associated, which holds the fair treatment and meaningful involvement of all people and communities in the development, implementation and enforcement of policies, laws and environmental regulations (Brulle and Pellow, 2006). Environmental quality can be addressed from a wide range of disciplines (Demography, Sociology, and Economics, to name a few). Yet the geographical science can perform spatial analyses, particularly through the use of Geographic Information Systems (Szasz and Meuser, 1997).

7 The spatial units in the study area are the 511 departments of Argentina which are grouped into 23 provinces and one Federal Disctrict (Figure 1). The country can also be analyzed from the six regions defined by the National Statistical System. Population of Argentina totalizes 40,091,359 inhabitants according to 2010 census (INDEC, 2012). 
Figure 1. Departments, provinces and regions.
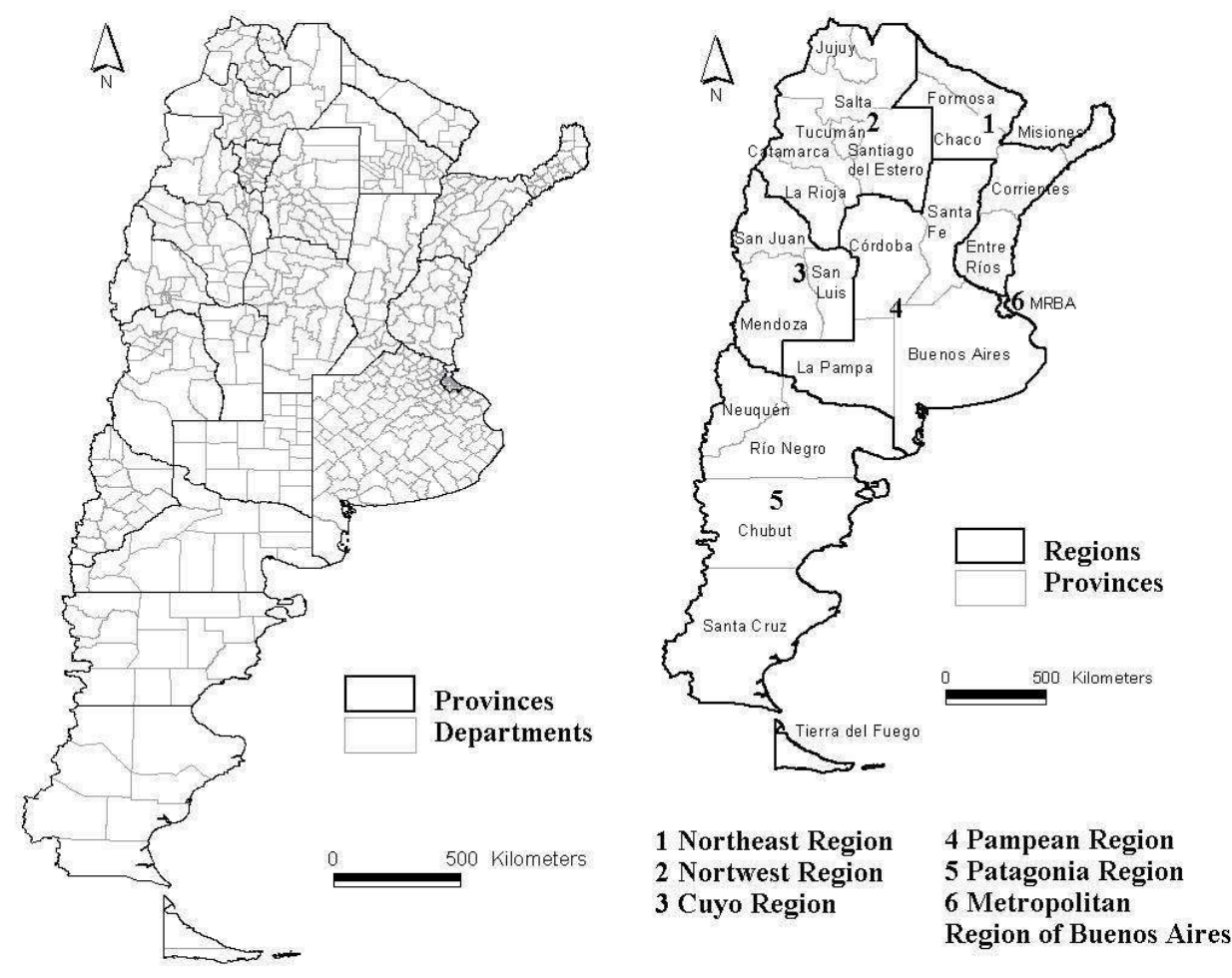

\section{Background and methodology} variables grouped into indicators that shape the state of a specific situation. These variables, applied to a specific territory, are not directly transferable to other areas, because they all have features and dynamics of their own.

grouping and weighting variables, there is always a subjective component. It is a relatively arbitrary process since no weighting structure can rationally justify the attribution of a greater weight to a given indicator (Tanguay et al., 2010). Moreover, membership of a variable to an indicator is not definitive since some may belong to more than one. For example, in Argentina parks and green spaces were created in almost all cases improving previously existing green areas, so we considered them as natural-based recreational resources and not as socially-constructed recreational resources (generally, no buildings are demolished to create "new green spaces"). Therefore grouping appears as a way to better organize data according to the similarity between the selected variables and the final purpose of the index.

In Argentina, several researchers developed indices at different scales considering the environmental dimension. While some were weighted using purely mathematical procedures (Marinelli et al., 1999; Cepeda et al., 2004; Boroni et al., 2005) others resorted to direct-subjective methods (Velázquez, op.cit.) with similar results from a spatial analysis viewpoint. Valpreda (2007), in turn, relied on other methods to assess variables, such as on the so-called Analytical Hierarchy Process - multicriteria approach - developed by Saaty (1980) and based on comparisons of pairs of criteria (variables) that can be used in 
environmental analyses (Balasubramaniam and Voulvoulis, 2005) and in urban studies associated with life quality (Mendez and Otizuki, 2001). Celemin and Lucero (2008) assigned direct weight to the dimensions of a quality of life index for Mar del Plata city, which also included an environmental component. Celemín and Velázquez (2012) constructed an index of environmental quality for the metropolitan area of Buenos Aires, combining subjective and objective variables. Finally, Velázquez (2010b) analysed the relationship between census data related to environmental risks, which are used in this work, and the socioeconomic structure of Argentina's provinces.

11 Our Environmental Quality Index (EQI) is composed of twenty-three variables, broken down into three major dimensions (Table 1):

Table 1. Indicators, variables, approach and sources for the Environmental Quality Index.

\begin{tabular}{|c|c|c|c|}
\hline \multicolumn{4}{|c|}{ Environmental quality index } \\
\hline Indicator & $\begin{array}{l}\text { Variable } \\
\text { (fuzzy standarization } \\
\text { mín } 0, \max 10 \text { ) }\end{array}$ & $\begin{array}{l}\text { Approach } \\
\text { Subjective } \\
\text { (direct) } \\
\text { Objective } \\
\text { (indirect) }\end{array}$ & Source \\
\hline \multirow{7}{*}{$\begin{array}{l}\text { Nature-based } \\
\text { recreational } \\
\text { resources } \\
\text { (30\% weight) } \\
\text { NBRR }\end{array}$} & A-Beaches & Subjective & $\begin{array}{l}\text { Municipal information/in situ work/ } \\
\text { satellite imagery }\end{array}$ \\
\hline & $\begin{array}{l}\text { B- Resort in streams, } \\
\text { rivers and lakes }\end{array}$ & Subjective & $\begin{array}{l}\text { Municipal information/ in situ work/ } \\
\text { satellite imagery }\end{array}$ \\
\hline & C- Natural spas & Subjective & $\begin{array}{l}\text { Municipal information/ in situ work/ } \\
\text { satellite imagery }\end{array}$ \\
\hline & $\begin{array}{l}\text { D- Presence of ice and } \\
\text { snow for winter } \\
\text { activities }\end{array}$ & Subjective & $\begin{array}{l}\text { Municipal information/ in situ work/ } \\
\text { satellite imagery }\end{array}$ \\
\hline & E- Relief & Subjective & $\begin{array}{l}\text { Municipal information/ in situ work/ } \\
\text { satellite imagery }\end{array}$ \\
\hline & F- Lakes and streams & Subjective & $\begin{array}{l}\text { Municipal information/ in situ work/ } \\
\text { satellite imagery }\end{array}$ \\
\hline & $\begin{array}{l}\text { G- Parks and green } \\
\text { open spaces }\end{array}$ & Subjective & $\begin{array}{l}\text { Municipal information/ in situ work/ } \\
\text { satellite imagery }\end{array}$ \\
\hline \multirow{3}{*}{$\begin{array}{l}\text { Socially } \\
\text { constructed } \\
\text { recreational } \\
\text { resources } \\
\text { (30\% weight) }\end{array}$} & $\begin{array}{l}\mathrm{H}-\text { Urban aesthetic / } \\
\text { urban heritage }\end{array}$ & Subjective & Municipal information/in situ work \\
\hline & I- Cultural centers & Subjective & Municipal information/ in situ work \\
\hline & $\begin{array}{l}\text { J- Shopping malls and } \\
\text { other amenities }\end{array}$ & Subjective & Municipal information/ in situ work \\
\hline
\end{tabular}




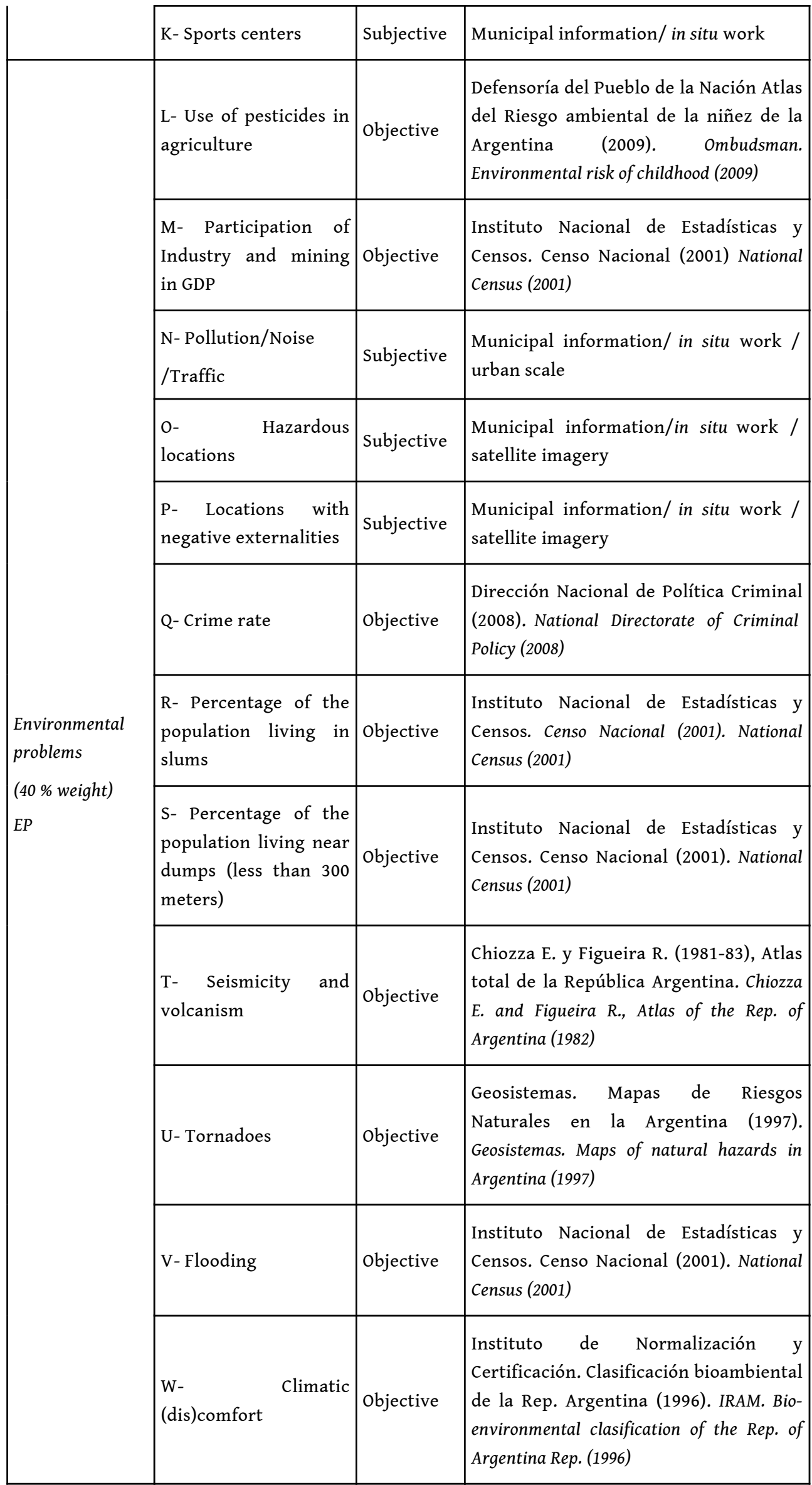


12 While most variables are self-explanatory, like those comprising the nature-based recreational resources indicator, others deserve further explanation. For instance, hazardous locations refer to places that produce, distribute or storage hazardous materials, e.g., nuclear facilities, pipelines, refineries, and military arsenals, among others. Regarding locations with negative externalities (or external costs), they comprise industrial production and logistics facilities capable of polluting the air, soil, and streams; and to generate heavy traffic due to product distribution. Unlike hazardous locations, this variable is associated with infrastructure located near cities.

In Argentina open pit mining (megaminería) is on the increase. This is common in Latin America but, in our opinion goes against sustainable development although it is situated in sparsely populated areas.

14 Climatic (dis)comfort is associated with Argentina large size, as well as its latitudinal and altitudinal development, Argentina offers a great variety of climates, very hot in north and very cold in south. The most populates cities are placed in temperate areas, which are in the centre of the country. Technically climatic comfort refers to the existence of combinations of environmental parameters (primarily temperature, humidity, radiation and wind) that do not cause stress on the human body. The range of climate comfort is very narrow: temperatures between $20^{\circ} \mathrm{C}$ and $25^{\circ} \mathrm{C}$ and relative humidity between $30 \%$ and approximately 70\% (Pérez Cueva, 2006). Out of these parameters there is a situation of discomfort. High surface temperature is regarded undesirable by most people; therefore, it can be used as an indicator of environmental quality (Lo and Faber, 1997; Nichol and Wong, 2005).

To assess nature-based recreational resources, each place was assumed to have a predominant attraction (beaches, topography, parks, lakes, etc.). Depending on their magnitude in relation to resident population, we assessed their predominant appeal on a scale ranging from 0 to 10 points. Other less relevant attractions were accounted for by assigning them additional points based on their quality.

There are very detailed theme maps which localize the main natural features (from thermal spas to fly fishing maps, to name a few) in its departments. This cartography was produced from 1996 to 2004 (Almirón et al., 2007).

To study socially-constructed recreational resources, we considered: Urban aesthetic and heritage, cultural centres as cinemas or theaters, shopping malls and sports centres. However each place has features of its own. For example, Trip (2007) considers relevant amenities, such as cafes, for the cities of Amsterdam and Rotterdam.

These resources are part of daily life and affect population wellbeing. As Santos postulated (1996), this is where geography can provide a significant contribution to other social sciences, because the everyday becomes defined by the place, i.e., the way people live their daily life and associate it to the territory. The assessment of socially constructed scenic and recreational resources relies on the assumption that each place usually has several attributes, which can also be valued. In this case, each "reproducible" (constructed) resource is quantified from 0 to 10 , and assigned a final score by setting a statistical mean.

19 As it can be seen, for both types of recreational resources, there is no specific guide of factors since they vary depending on the place and information available. We tried to emphasize the predominant attractions of each district (whether natural or social). However, unlike social constructed features, natural based features are non-reproducible, 
although they can be improved. This has an impact on their selection and differential weighting.

Despite the fact that we initially considered turning these features into data by establishing a ratio between lakes or green spaces areas and population, for example, we decided to emphasize quality as not all green spaces and streams have different qualities. For instance, many watercourses are highly polluted and many green places have been abandoned; some even lack trees and are used for illegal dumping. These features were qualified rather than quantified, and this is where professional knowledge came in handy, just like it would do for a researcher conducting an environmental impact assessment. This could also be applied to the socially constructed component of the index. As mentioned above, a quality index should not only contemplate objective data but also perceptions (Marans, 2003) gathered from the resident population via surveys or by qualified professionals. The use of subjective approaches is already present in the environmental field: is a very common practice in the environmental impact assessment (EIA), mainly based on professional expertise. Appraisals of the expert engaged in an environmental impact assessment play a significant role in its results due to the considerable subjective decision- making upon which EIA is based (Wilkins, 2003, p. 401). We can say that there is some parallelism between this affirmation and our proposal of selection and measurement of variables where, just like in the EIA, professional expertise, intuition and value judgement are acknowledged (Weston, 2000).

21 Environmental problems can be construed as processes with negative effects on environmental sustainability, including society. If environmental problems are not measured, there is no objective way of quantifying the magnitude of the environmental impact (Fernández, 2000). This indicator includes twelve possible problems. Unlike the two previous dimensions, this one uses primarily secondary data provided mainly by various departmental, provincial and national organizations.

As seen in Table 1, we value indicators with different weights: $30 \%$ nature-based recreational resources, $30 \%$ socially-constructed recreational resources and $40 \%$ environmental problems. Recreational resources (NBRR and SCRR) outweigh the problems (EP) because while problems can be mitigated, RR influenced by the natural basis are less modifiable, at least in Argentina. The detailed explanation of this valuation and the construction of the index omega scores is in Velázquez and Celemín (2013).

\section{Results and discussion}

The index yielded very different values throughout Argentina. We resorted to the natural breaks classification method (Jenk's optimization) which minimizes the sum of the variance within each class. The maximum value was obtained in the department of Junín (province of San Luis) with 8.41 points, and the minimum in Limay Mahuida (La Pampa) with 4.17 points. departments of Argentina belong to the 8 or higher score group. 
Figure 2. Spatial analysis of the EQI map.

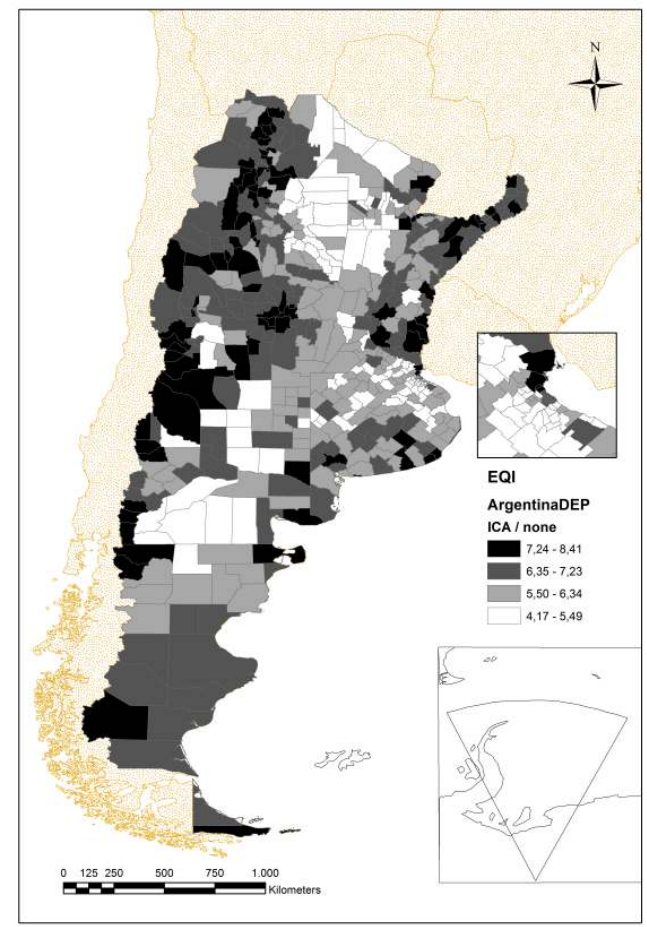

\section{thes} these units provide attractive landscapes including mountain ranges, lakes and lush vegetation (NBRR). In general, Socially Constructed Recreational Resources (SCRR) complement the attractiveness, and environmental problems are relatively mild.

Six departments in Cuyo Region are part of this higher category, too. This is ascribed to the presence of attractive mountain ranges and other natural resources (thermal springs, spas). In general terms, SCRR properly accompany this framework, especially regarding provincial capital cities. And so does the value of the environmental problems which are relatively low.

In Patagonia Region, four departments reach this level in the EQI where mountainous landscapes combine with glacial attractions, forests and hot springs. Indeed there is an interesting SCRR provision accompanied by a relative absence of environmental problems.

In the Pampas region, the department containing the city of Mar del Plata (main beach resort of the country) has an abundant offer of Nature-Based Recreational Resources (NBRR). Mar del Plata lies on the Atlantic coast, has ranges in the vicinity, and a wide frame of SCRR associated with an intense summer activity; environmental problems are more complex than in other sites, though not serious enough to offset its assets.

Finally, it should be noted that there are two regions, Metropolitan Region of Buenos Aires (MRBA, see zoom in figure 2) and in the North-East Region (NER), whose departments do not exceed the 8 points.

30 With a score ranging from 7.24 to 7.99 points there is a set of 75 departments. Within the North-West Region (NWR) there is a relatively large group of spatial units located in the central corridor where the combination of relief, vegetation, water availability, historic 
villages and towns and the relative scarcity of environmental problems contribute positively to its valuation.

Only 12 departments from the North-East Region (NER) integrate this group: 1) the departments containing the provincial capitals (Chaco, Formosa, Corrientes and Misiones) stand out more for their SCRR than for their NBRR; 2) 5 departments form the sub-tropical province of Misiones due to their lush vegetation combined with ranges that create an interesting topography (waterways, waterfalls), reasonable SCRR endowment and relatively few environmental problems; at last 3) 2 departments from Corrientes province with plentiful resources.

Cuyo Region stands out for its mountainous landscapes. The Andes mountain range, further favoured by the combination of relieves, streams and oases complement SCRR relatively well without major environmental problems.

In the Pampas, the rivers in Entre Ríos province, the large segment of hills and ranges in Córdoba province, the Atlantic coast, two ranges in Buenos Aires Province are the most significant NBRR. This relatively heterogeneous group comprises hot springs and river beaches in Entre Ríos, mountains and resorts in Córdoba, beaches and small ranges in Buenos Aires, and streams and spas in La Pampa. The existence of SCRR varies according to the size of the cities. They predominate in the most populated districts of Córdoba and Buenos Aires provinces.

This group also includes several Andean departments of the Patagonia region together with some coastal units from this same region. While the former stand out for their mountain ranges and ample SCRR, the latter feature beaches, wildlife, and ranges that are adequately supported by SCRR.

Within the MRBA, only two departments located on the Parana Delta banks can be found in this group.

The lowest EQI scores (4.17 to 5.49 points) concentrate primarily in the north of the country, particularly in a wide strip of land lying between the NWR and the NER, mainly inside Formosa, Santiago del Estero and Chaco provinces. The low score can be attributed to the extreme shortage of NBRR. The arid or semi-arid environment in conjunction with a plain landform, sparse vegetation, waterways and lagoons turn nature-based attractions very scarce in this region. Moreover, the absence of relatively large cities along with the great deficiencies (not only environmental, but fundamentally socioeconomic) explain the lack of SCRR. This situation exacerbates, on certain occasions, due to environmental problems arising from deforestation, intensive use of agrochemicals and oil exploration. All these factors configure a highly adverse scenario especially for the indigenous populations confined in this area (Velázquez, 2008).

In the Pampas, some other areas exhibit very low values, such as the Salado River basin (Buenos Aires), western La Pampa, large areas of Santa Fe and one department in Entre Ríos. In the Salado River basin or "depressed pampa", the only NBRR found are particularly small lagoons and lowland rivers with very few SCRR. Most cultural and leisure activities in this small cattle raising towns are overshadowed by their close proximity to Buenos Aires city. The environmental problems include: floods, agrochemicals use, poor waste disposal practices, proximity of water tables to the surface, and lack of services.

38 This is mirrored in large areas of Santa Fe province, where the lack of NBRR (plains monotony, absence of suitable waterways for leisure purposes) and SCRR (multiplicity of 
rural small towns) in a context of environmental problems: use of agrochemicals and presence of certain industrial activities explain the meagre score achieved. The western Pampas also features very few NBRR (homogeneity of relieve, aridity, lack of water courses), virtual absence of SCRR (scattered population, low income and education level, conservative social structure, lack of state interest in addressing matters related to recreational opportunities, for example). Environmental problems are also present, mainly through spontaneous garbage dumping. In Entre Ríos, only one department is part of this group, owing to its geographical location: far away from the two large river corridors that embrace this province, combined with scarce SCRR.

In Cuyo Region, there are two areas that cross southern Mendoza and San Luis which belong to this group. In both cases, there is an arid and flat surface with scarce vegetation without water courses and very low population density. Into Patagonia Region, they lie in this feature a large section of Río Negro province and central Chubut. Although some scenic resources outstand thanks to the relief of the plateau, they are overshadowed by droughts, low plant cover (compounded by overgrazing) and scarce water courses. The situation of SCRR is even worse, as the small and scattered population suffers a significant degree of isolation and the environmental problems are mostly linked to climate discomfort.

Finally the MRBA yields the highest proportion of departments in this category. Population concentration in this metropolis is accompanied by a serious lack of NBRR, usually limited to few places called green spaces. The overpowering presence of cement favours flooding in this flat city where most waterways are cased. Regarding SCRR, the picture is quite diverse but mostly limited to financially sound markets. This amalgam affects mostly the low-income populations in the suburbs for whom the possibilities of public or popular entertainment are generally very limited. For the higher-income class, the range of opportunities is wider but, more often than not, involves commuting long distances. More general environmental problems, as pollution, noise and traffic congestion, are associated mainly with the urban scale and unsustainable growth.

41 The remaining departments of Argentina lie at intermediate levels, with varying degrees of contradiction between their NBRR endowment, SCRR and environmental problems.

42 In general terms, the NWR appears to be in relatively "good shape", except for the eastern fringe. In the NER, a vast array of situations coexist, being more favourable in Misiones and Corrientes provinces and less so in Formosa and Chaco provinces, chiefly inside the provinces. The Pampas region also varies widely yielding relatively good performance in Entre Ríos and Córdoba, and poor in Santa Fe and La Pampa. Buenos Aires exhibits wide contrasts between the basin of the Salado River and the southern area, which registers better values. The Patagonia is also fragmented. On the one side the mountains with high scores and the coast with relatively lower ones and on the other the plateau, especially to the north, with adverse conditions. Finally the MRBA offers, with a few exceptions, poor environmental conditions to most of its residents as well as a remarkable lack of NBRR and fragmented SCRR.

43 As it can be noticed, the department with the highest EQI score is Junín (San Luis province), in Cuyo Region. It is followed by Manuel Belgrano, in the NWR, where the capital of Jujuy province is situated. The first department of the Patagonia region, Bariloche, ranks fourth; while in the $12^{\text {th }}$ place is the first department of the Pampas, General Pueyrredón, which is mainly composed by the sea side city Mar del Plata. We must reach number 40 for the highest site in the NEA, corresponding to Puerto Iguazú, in 
Misiones province. Finally, the top positioned unit in the MRBA is Tigre, reaching number 68.

It can also be noticed that Limay Mahuida, in La Pampa, is the department with the worst performance, ranking $511^{\text {th }}$; being also the worst of the Pampas region. It ranks very close to President Perón, in the MRBA at number 510. The worst department in the North-West Region is Rivadavia (Salta), ranking $509^{\text {th }}$; and $506^{\text {th }}$ appears Norquinco (Rio Negro) in Patagonia Region. Mitre (Santiago del Estero) ranks 504 being the poorest score in the NWR. Finally, Lavalle (Mendoza) appears in the position 441, being the worst department of Cuyo Region.

None of the departments located in the MRBA reaches a prominent position in EQI. Despite the high degree of heterogeneity between both extremes, the average from all the departments of MRBA is the lowest of all the regions. NBRR are extremely inadequate and SCRR very asymmetric in a context of major environmental problems associated with a metropolis where $14,819,137$ inhabitants live into $2,681 \mathrm{~km}^{2}$.

An urban scale analysis also shows regional disparities in the performance of the index (Table 2). Large cities, however, tend to occupy favourable positions in the Environmental Quality Index. This is linked to a relatively high endowment of SCRR with respect to the local population size. They are followed by major mid-sized cities which also show certain degree of dispersion. Major towns also vary widely among themselves, especially regarding NBRR availability in the regional context. This group has poor performance, probably due to the relative scarcity of SCRR. Finally small towns and rural populations present a high degree of variation as, once again, their NBRR differs significantly depending on the region under study. The lowest performance of this category goes hand in hand with the lack of SCRR.

Table 2. Best and worst departments according to EQI dimension and urban scale.

\begin{tabular}{|c|c|c|c|c|c|c|}
\hline & $\begin{array}{l}\text { MRBA } \\
(>10,000,000)\end{array}$ & $\begin{array}{l}\text { Large cities } \\
(1,000,000- \\
9,999,999 .)\end{array}$ & $\begin{array}{l}\text { Mid-sized } \\
\text { cities }(400,000 \\
-999,999)\end{array}$ & $\begin{array}{l}\text { Small cities } \\
(50,000 \\
399,999)\end{array}$ & $\begin{array}{l}\text { Towns } \\
(20,000 \\
49,999)\end{array}$ & $\begin{array}{l}\text { Small towns } \\
\text { and rural } \\
\text { population } \\
(<\quad 20,000 \\
\text { inhab.) }\end{array}$ \\
\hline $\begin{array}{l}\text { Top } \\
\text { ranked }\end{array}$ & Tigre, 68th & $\begin{array}{l}\text { Capital } \\
\text { (Córdoba) } \\
27 \text { th }\end{array}$ & $\begin{array}{l}\text { General } \\
\text { Pueyrredón } \\
\text { (Buenos Aires) } \\
\text { 12th }\end{array}$ & $\begin{array}{l}\text { Dr Manuel } \\
\text { Belgrano } \\
\text { (Jujuy) 2th }\end{array}$ & $\begin{array}{l}\text { Junín (San } \\
\text { Luis) 1th }\end{array}$ & $\begin{array}{l}\text { Los Lagos } \\
\text { (Neuquén) } \\
\text { 9th }\end{array}$ \\
\hline $\begin{array}{l}\text { Worst } \\
\text { ranked }\end{array}$ & $\begin{array}{l}\text { Presidente } \\
\text { Perón, 510th }\end{array}$ & $\begin{array}{ll}\text { Rosario } & \\
\text { (Santa } & \text { Fe) } \\
104 \text { th } & \end{array}$ & $\begin{array}{l}\text { Ensenada } \\
\text { (Buenos Aires) } \\
\text { 506th }\end{array}$ & $\begin{array}{l}\text { Chivilcoy } \\
\text { (Buenos } \\
\text { Aires) } \\
475 \text { th }\end{array}$ & $\begin{array}{l}\text { Rivadavia } \\
\text { (Salta) } \\
509 \text { th }\end{array}$ & $\begin{array}{l}\text { Limay } \\
\text { Mahuida (La } \\
\text { Pampa) } \\
\text { 511th }\end{array}$ \\
\hline $\begin{array}{l}\text { Average } \\
\text { RRBN }\end{array}$ & | 2.7 & \begin{tabular}{|l}
7.1 \\
\end{tabular} & 5.9 & 6.2 & 5.4 & 5.3 \\
\hline $\begin{array}{l}\text { Average } \\
\text { SCRR }\end{array}$ & \begin{tabular}{|l}
$\mid$ \\
6.1
\end{tabular} & 8.9 & 7.1 & 5.8 & 4.7 & 3.7 \\
\hline
\end{tabular}




\begin{tabular}{|l|l|l|l|l|l|l|}
\hline $\begin{array}{l}\text { Average } \\
\text { EP }\end{array}$ & 2.6 & 3.1 & 2.6 & 2.0 & 1.7 & 1.4 \\
\hline $\begin{array}{l}\text { Average } \\
\text { EQI }\end{array}$ & 5.6 & 7.6 & 6.8 & 6.8 & 6.3 & 6.2 \\
\hline
\end{tabular}
each one departmental units (see sources in Table 1) and selecting variables with their respective weights. Some variables that we would expect to include (e.g. water quality or air pollution) are not available on the same basis and could not be considered.

The index shows good performance in large and mid-sized cities and yields the worst scores in some of the cities belonging to the Metropolitan Region of Buenos Aires, due to the presence of a wide range of severe environmental problems. 


\section{BIBLIOGRAPHIE}

ALMIRÓN A., TRONCOSO C. \& LOIS C. (2007), "Promoción turística y cartografía. La Argentina turística en los mapas de la Secretaría de Turismo de la Nación (1996-2004)”, Investigaciones Geográficas, 62, pp. 138- 154. [in Spanish]

ANDREWS C. (2001), “Analyzing Quality-of-Place”, Environment and Planning B : Planning and Design, 28, 2, pp. 201-217.

BALASUBRAMANIAM A. \& VOULVOULIS N. (2005), “The appropriateness of Multicriteria Analysis in environmental decision-making problems", Environmental Technology, 26, 9, pp. 951-62.

BORONI G., GÓMEZ LENDE S. \& VELÁZQUEZ G. (2005), “Geografía, calidad de vida y entropía. Aportes de la teoría de la información para la construcción de un índice de calidad de vida a escala departamental (1991-2001)", in VELÁZQUEZ G. \& GÓMEZ LENDE S., Desigualdad y Calidad de Vida en la Argentina (1991-2001). Aportes empíricos y metodológicos, Tandil, Reun, pp. 63-86. [in Spanish]

BRULLE R. \& PELLOW D. (2006), “Environmental justice : Human Health and Environmental Inequalities", The Annual Review of Public Health, 27, pp. 103-124.

CATALAN-VAZQUEZ M. \& JARILLO-SOTO E. (2010), "Paradigmas de investigación aplicados al estudio de la percepción pública de la contaminación del aire”, Revista Internacional de Contaminación Ambiental, 26, 2, pp. 165-178. [in Spanish]

CELEMÍN J. \& VELÁZQUEZ G. (2012), "Proposal and application of an environmental quality index for the Metropolitan Area of Buenos Aires, Argentina", Geografisk Tidsskrift-Danish Journal of Geography, 112, 1, pp. 15-26.

CELEMÍN J. \& VELÁZQUEZ G. (2011), "Propuesta y aplicación de un índice de calidad ambiental para la Ciudad y Provincia de Buenos Aires (Argentina)", Journal of Latin American Geography, 10, 1, pp. 69-82. [in Spanish]

CEPEDA R., MARINELLI C, GÓMEZ LENDE S. \& VELÁZQUEZ G. (2004), “Técnicas de análisis multivariado para la determinación de calidad de vida", Memorias del Primer Seminario argentino de geografía cuantitativa, 26-27 de agosto, Buenos Aires, Argentina. [in Spanish]

CHIOZZA E. (1979), El país de los Argentinos. Nuestras fronteras, Buenos Aires, Centro Editor de América Latina. [in Spanish]

CHIOZZA E. \& IGLESIAS A. (1981-1983), Atlas total de la República Argentina, Buenos Aires, Centro Editor de América Latina. [in Spanish]

CHIOZZA E., FIGUEIRA R. \& IGLESIAS A. (1987), Atlas total de la República Argentina, Buenos Aires, Centro Editor de América Latina. [in Spanish]

DEFENSORÍA DEL PUEBLO DE LA NACIÓN (2009), Atlas del Riesgo ambiental de la niñez de la Argentina, PNUD-UNICEF-OPS-OIT, http://defensoresymedios.org.ar/wp-content/uploads/2010/04/ Atlas.pdf (Last accessed April 8, 2012). [in Spanish]

DIRECCIÓN NACIONAL DE POLÍTICA CRIMINAL (2008), Estadísticas en Materia de Criminalidad. Ministerio de Justicia, Seguridad y Derechos Humanos, Presidencia de la Nación, Consultado marzo 
2010, http://www.jus.gob.ar/areas-tematicas/estadisticas-de-politica-criminal/mapa.aspx (Last accessed April 12, 2012). [in Spanish]

ESCOBAR L. (2006), "Indicadores sintéticos de calidad ambiental : un modelo general para grandes zonas urbanas", Eure, 32, 96, pp. 73-98. [in Spanish]

FERNÁNDEZ R. (2000), La ciudad verde : teoría de la gestión ambiental urbana, Buenos Aires, Espacio Editorial. [in Spanish]

FISHBEIN G. (1969), “The real meaning of environmental quality”, American Journal of Public Health 59, 12, p. 2130.

GEOSISTEMAS (1997), Mapa de riesgos naturales en la Argentina, Buenos Aires, Geosistemas. [in Spanish]

HERZER H. \& GUREVICH R. (1996), “Degradación y desastres : parecidos y diferentes : tres casos para pensar y algunas dudas para plantear”, in FERNÁNDEZ M. Ciudades en riesgo, Quito, Red de Estudios Sociales en Prevención de Desastres en América Latina, pp. 75-91.

INSTITUTO NACIONAL DE ESTADÍSTICAS Y CENSOS (2003), PBG por provincia y sector de actividad económica, http://www.mecon.gov.ar/secpro/dir_cn/documentos/ producto_bruto_geografico.xls (Last accessed March 20, 2012). [in Spanish]

INSTITUTO NACIONAL DE ESTADÍSTICAS Y CENSOS (INDEC) (2012), Censo nacional de población, hogares y vivienda 2010, Buenos Aires, www.censo2010.indec.gov.ar (Last accessed March 14, 2013). [in Spanish]

IRAM (1996), Clasificación bioambiental de la República Argentina, Buenos Aires, Instituto Argentino de Normalización. [in Spanish]

LO C. \& FABER J. (1997), “Integration of Landsat Thematic Mapper and census data for quality of life assessment", Remote Sensing of Environment, 62, 2, pp. 143-157.

LORENZINI H. y REY BALMACEDA R. (1999), Geografía de la Argentina, Buenos Aires, AZ Editora. [in Spanish]

LUCERO P. \& CELEMÍN J. (2008), “La calidad de vida de la población en la determinación de la calidad territorial. Un estudio de autocorrelación espacial aplicado a la ciudad de Mar del Plata, Argentina", Geofocus, 8, pp. 94-114. [in Spanish]

MARANS R. (2003), “Understanding environmental quality through quality of life studies : the 2001 DAS and its use of subjective and objective indicators", Landscape and Urban Planning, 65, 1, pp. 73-83.

MARINELLI C., TORCIDA S., CEPEDA R., GARCÍA M. \& VELÁZQUEZ G. (1999), “Un procedimiento alternativo para la selección estadística de variables de calidad de vida”, in VELÁZQUEZ G., Calidad de Vida Urbana : aportes para su estudio en Latinoamérica, Tandil, Centro de Investigaciones Geográficas, pp. 133-142. [in Spanish]

MENDES J. \& MOTIZUKI W. (2001), "Urban quality of life evaluation scenarios : The case of Sao Carlos in Brazil”, CTBUH Review, 1, 2, pp. 13-23.

METZGER P. (2006), "Medio ambiente urbano y riesgos : elementos de reflexión”, in FERNÁNDEZ M., Ciudades en riesgo, Quito, Red de Estudios Sociales en Prevención de Desastres en América Latina, pp. 43-56. [in Spanish]

NICHOL J. \& WONG M. (2005), “Modeling urban environmental quality in a tropical city”, Landscape and Urban Planning 73, 1, pp. 49-58. 
NISSAN E. (1997), "Rating and Ranking Metro Areas in the United States and Canada for the Arts and Recreations", Journal of Regional Analysis and Policy, 27, 1, pp. 47-54.

PÉREZ CUEVA A. (2006), “Ciudad y confort ambiental : estado de la cuestión y aportaciones recientes”, Cuadernos de geografía, 80, pp. 147-182. [in Spanish]

RAHMAN T., MITTELHAMMER R. y WANDSCHNEIDER P. (2003), “Sensitivity Analysis of Quality of Life Indices Across Countries”, American Agricultural Economics Association, Annual Meeting, July 27-30. Montreal, Canada.

SAATY T. (1980), The Analytic Hierarchy Process, Nueva York, McGraw-Hill.

SÁNCHEZ D. (2011), “Indicadores turísticos en la Argentina : Una primera aproximación”, Investigaciones Turísticas, 2, pp. 29-65, [in Spanish]

SANTOS M. (1996), A Natureza do Espaço. Técnica e tempo. Razâo e emoçâo, Sâo Paulo, Hucitec. [in Portuguese]

SZAZ A. \& MEUSER M. (1997), “Environmental Inequalities : Literature Review and Proposals for New Directions in Research and Theory”, Current Sociology, 45, 3, pp. 99-120.

TANGUAY G., RAJAONSON J., LEFEBVRE J. \& LANOIE P. (2010), "Measuring the sustainability of cities : A survey-based analysis of the Use of Local Indicators", Ecological Indicators, 10, 2, pp. 407-418.

TRIP J. (2007), “Assessing quality of place : a comparative analysis of Amsterdam and Rotterdam”, Journal of Urban Affairs, 29, 5, pp. 501-517.

VALPREDA C. (2007), “Sistema de Información Geográfica (SIG), teledetección y evaluación multicriterio (EMC) en un estudio de evaluación de impacto ambiental (EIA)", Memorias XI Conferencia Iberoamericana de Sistemas de Información Geográfica, 29-31 de mayo, Buenos Aires, Argentina. [in Spanish]

VAN KAMP I., LEIDELMEIJER K., MARSMANA G. \& DE HOLLANDER A. (2003), “Urban environmental quality and human well-being. Towards a conceptual framework and demarcation of concepts ; a literature study", Landscape and Urban Planning, 65, 2, pp. 5-18.

VELÁZQUEZ G. (2001), Geografía, calidad de vida y fragmentación en la Argentina de los noventa. Tandil, Centro de Investigaciones Geográficas. [in Spanish]

VELÁZQUEZ G. (2008), Geografía y Bienestar. Situación local, regional y global de la Argentina luego del Censo de 2001, Buenos Aires, Eudeba. [in Spanish]

VELÁZQUEZ G. (2010a), “Geografía y bienestar en la Argentina. La desigualdad regional a comienzos del XXI", in TORRADO S. (ed.), El costo social del ajuste (Argentina, 1976-2002) (Tomo II), Buenos Aires, Edhasa, pp. 335-357. [in Spanish]

VELÁZQUEZ G. (2010b), “Environmental risks, demographic dynamic and Life Quality. Argentina at beginning of XXI Century", Acta Universitatis Carolinae-Geographica, 2, pp. 123-142.

VELÁZQUEZ G, CELEMÍN J.P. (2013) La calidad ambiental en la Argentina. Análisis regional y departamental (2010), Tandil, Centro de Investigaciones Geográficas. [in Spanish]

WESTON J. (2000), "EIA decision-making theory and screening and scoping in UK practice", Journal of Environmental Planning and Management, 43, 2, pp. 185-203.

WILKINS H. (2003), “The need for subjectivity in EIA : discourse as a tool for sustainable development", Environmental Impact Assessment Review, 23, 2, pp. 401-414. 


\section{RÉSUMÉS}

Pour évaluer la qualité de vie de la population, il faut tenir compte de plusieurs facteurs y compris la dimension environnementale, de plus en plus souvent présente dans l'appréciation de la qualité de vie. Le développement d'indicateurs vise à mieux comprendre les questions liées aux différentes dimensions associées au bien-être de la population. Un indice de la qualité de l'environnement a été élaboré, s'appliquant aux 511 départements de l'Argentine pour l'année 2010. Il est composé de vingt-trois variables regroupées en trois dimensions, à savoir : a) les ressources naturelles de loisirs; b) les ressources récréatives socialement construites; c) les problèmes environnementaux. La première dimension de l'indice montre une distribution spatiale asymétrique et présente un fort déficit dans la région métropolitaine de Buenos Aires, la capitale du pays. La deuxième dimension se présente avec des valeurs plus élevées dans les grandes et moyennes villes et la région métropolitaine de Buenos Aires. Enfin, les principaux problèmes environnementaux sont étroitement liés aux grandes zones urbaines.

To evaluate the population Quality of Life, several factors should be considered, including the environmental dimension, which has gained notorious attention in the study of this subject. The development and use of indices has become increasingly necessary in order to understand and properly grasp the problems linked to the different dimension associated with population wellbeing. An Environmental Quality Index (EQI) made up of twenty-three variables grouped into three dimensions known as: a) nature-based recreation resources, b) socially constructed resources, and c) environmental problems is applied to the 511 departments of Argentina in 2010. The first dimension of the index yields a very asymmetric distribution along the Argentine territory, and evidences a strong deficit in the metropolitan region of Buenos Aires city, the capital of the country. The second dimension exhibits greater relative presence in large and midsized cities and in the metropolitan region of Buenos Aires. At last, the presence of environmental problems is strongly showed to large urban areas.

\section{INDEX}

Keywords : quality of life, environmental dimension, Argentina

Mots-clés : qualité de vie, dimension environnementale, Argentine

\section{AUTEURS}

\section{GUILLERMO ÁNGEL VELÁZQUEZ}

Centro de Investigaciones Geográficas (CIG), Instituto de Geografía, Historia y Ciencias Sociales (IGEHCS), gvelaz@fch.unicen.edu.ar

\section{JUAN PABLO CELEMÍN}

Centro de Investigaciones Geográficas (CIG), Instituto de Geografía, Historia y Ciencias Sociales (IGEHCS),jpcelemin@conicet.gov.ar 